\title{
Co-integration analysis between stock prices \& exchange rates: Evidence from Pakistan
}

\author{
Asim Rafiq ${ }^{1}$, Syed Shabib ul Hasan ${ }^{2}$ \\ ${ }^{1}$ PhD scholar at University of Karachi. \\ ${ }^{2}$ Chairman Department of Public Administration, University of Karachi. Pakistan \\ *Corresponding author E-mail: asim_r83@hotmail.com
}

\begin{abstract}
Objective: The objective of the study is to investigate the relationship between stock prices represent by (KSE100 index) and Exchange rates in case of Pakistani economy. Methodology: Quarterly data from 1993 to 2010 has been used for the study \& cointegration technique applied to examine the relationship between KSE 100 index \& Pakistani currency in terms of rupees per dollar. Findings: The results suggest that the residual from the OLS regression are non-stationary at level using critical values suggest by Davidson and MacKinnon (1993) so there is no co-integrated relationship found between stock prices \& exchange rates. Conclusion: study can be concluded with the view that there is no long term relationship between stock prices \& exchange rates.
\end{abstract}

Keywords: Stock Prices; Exchange Rate; Co-Integration; KSE100 Index; Co-Movement.

\section{Introduction}

In early 1990s relationship between stock \& foreign exchange market attracted the attention of the academicians, financial analyst \& researchers. Elimination of Foreign exchange controls \& capital inflow barriers, emergence of new capital markets, more flexible exchange rate arrangements were significant features of last quarter of the preceding century. These two markets have a paramount importance in financial system so understand the mutual relationship between foreign exchange and stock market has received more attention of the researchers even now than before.

Since the inception of this century global economies has faced recent financial crisis due to financial instability of Europe \& debt crisis in United States volatility have drastically surge in both Foreign \& stock market. Both markets faced periods of upturn and down turn \& have intense attention of global investment community. Theoretically there is disagreement on direction or on the existence of the relationship between exchange rates and equity prices.

There are two approaches of exchange rates determination "Flow Oriented Model" \& "Stock Oriented Model". According to the flow model exchange rate is determined by trade balance performance and current account of a country. Dornbusch and Fisher (1980) there is negative correlation between exchange rates \& stock prices \& causality runs from exchange rates to stock prices. Other side, according to "Stock Oriented Model (SOM) by Branson and Frankel (1983) there is positive correlation between exchange rate and stock prices and causality runs from stock prices to exchange rates. There is no conclusive evidence in the literature regarding the interaction between exchange rate and stock prices. So it becomes imperative to investigate the relationship between stock prices and exchange rates in Pakistan.

KSE 100 index was launched in 1991 the 1000 points was initial base \& this period is regarded as steady growth period.
In December, 2007 record the barrier of the 14000 (the highest ever benchmark points). (Akhtar, 2015). In the wake of 2008 index crossed the 15000 point bench mark (Fig.1) but during the year some unpleasant environment was seen by the stock market due to the Global financial crises \& its consequence on the Pakistani stock market. This period was regarded as a crises period. During the 2009-10 index starts to recover however, in 2011-2012 the index breached the benchmark of the $16000 \&$ this the period in which KSE was considered as the best emerging market in the ASIA.

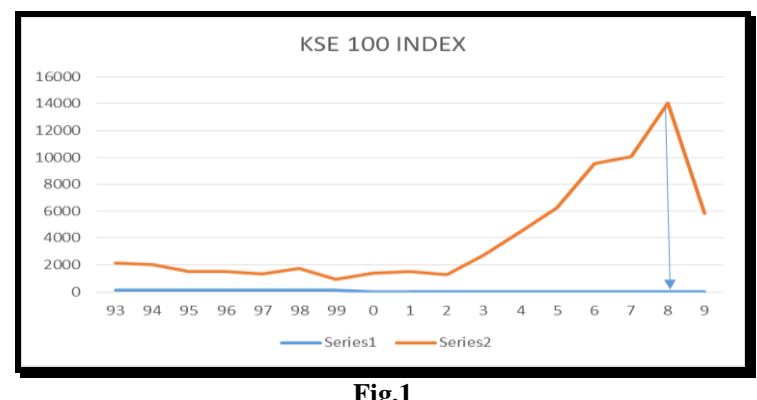

If we analyze the exchange rate in Pakistan over last two decades we came to know that the exchange rate trending upward in the long run but if break this long term trend into short run and intermediate trend it appears that the exchange rate was at increasing trend but at very slow rate but after 2008 the rate has speed up and almost touched the barrier of 100Rs per US Dollar (Fig.2) so to maintain exchange rate for the economic growth has been a cause of concern for policy maker, investor, currency traders and exporters. 


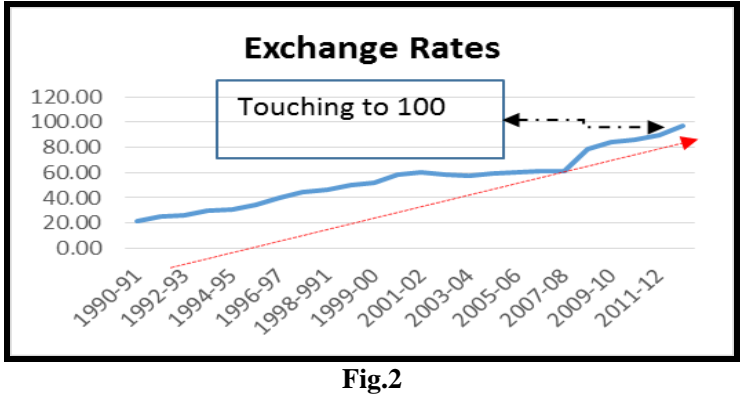

Both variables trending upward but exchange rate with a steady rate from 1991 to 2007 but after that there is no clear pattern appears so it becomes imperative to investigate this relationship in case of Pakistan.

\section{Literature review}

(Keung \& Farooq 2004) conducted a research to find the impact of exchange rates on the stock returns. Indices used are General index, Karachi stock exchange; four indices, three sector indices. Researchers used Granger cause test to find causality \& found bidirectional causality between the exchange rates \& stock returns. (Kim 2003) found having adopted the free floating exchange rates system by the many countries worldwide since 1973 the economist, investors \& policy makers are keenly interested in determining the factors those affects the behavior of the stock, commodity $\&$ currency market. Exchange rates have become the significant factor in contributing the stock prices \& firm profitability with the increasing global trade $\&$ capital movements.

During the financial crises countries stock, commodity \& currencies markets affected if any relationship exist risk in the one market can be reduced by controlling the other market. Investment portfolios of multinational \& national companies are affected by the GDP, exchange rates, interest rates \& gold prices (Jorion 1990).

If we can say that the real exchange rates increases \& the firms' profitability decrease it will ultimately affect the stock prices of those firms. If causation runs from stock prices to exchange rate policy makers can stabilize the stock markets by stabilizes the economic policies. Knowledge of the relationship between these two variables serves as guide line for policy making for economic \& financial planning (Hastemi-J and Roca 2005).

(Morales 2007) did a study to examine the dynamic relationship between stock prices \& exchange rate of four European markets Hungary, Slovakia, Czech Republic \& Poland. Stock prices \& exchange rate data is gathered from the four countries as well as data of stock prices is also collected of United States, United Kingdom \& from Germany. Daily data is obtained from 1999 to 2006. Both long run \& short analysis was done. Vector Error Correction model, Johansen co integration \& Granger causality applied to find an association between these two variables. Study confirmed that there is both no long or short run association between these two factors except Slovakia. Causality test found that a unidirectional causal relationship from the exchange rates to stock prices in case of Czech Republic, Hungary \& Poland. There was more result of causality from Slovakian exchange rates to the United Kingdom stock prices, Hungarian exchange rate to the United Kingdom stock prices, from the Czech Republic exchange rate to the United Kingdom stock prices \& from the Polish exchange rates to the United Kingdom stock prices. Finally the result also showed causality from the stock prices to the stock prices in the case of United States to Poland, Hungary to United Kingdom \& United Kingdom to Poland.

(Nath and Samanta 2003) researched on the relationship between exchange rate \& stock prices in India. During the period examine the Indian stock market had been growing $\&$ through deregulation restrictions of foreign investment policy were relaxed in addition in 1990 reforms are made in the Indian financial sector by com- plying international practices in financial market. Also the American depository \& Global depository receipts make foreign investors to invest in Indian financial markets about USD 15 billion, this allowed to flow of fund in Indian financial market \& \& Indian rupee affected from this activity. Granger Causality test applied to examine the relationship between the variables. Daily data is taken using the stock index S\&P CNX NIFTY of National Stock Exchange from 1993-2002.For exchange rate time period divided in buckets due to conversion of exchange rate system that is determine by the market forces. Finally study conclude generally, that there is no association between these variables, however equity market returns cause on exchange rates return with the little possibility of casual effect on reverse direction.

(Phylaktis and Ravazzolo 2005) did a study to explore the relationship between stock prices \& exchanges rates for group of $\mathrm{Pa}-$ cific Basin countries. Study aims to identify long term association between the Foreign exchange markets or stock exchange markets? In recent years has the relationship changed due to international investors? Was relationship affected by the 1997 financial crises? To know the direction of the causality \& the consequences of the transmission shocks? Can domestic equity markets can be separated from global markets? For the analysis five Pacific Basin countries were selected including Thailand, Malaysia, Philippines, and Hong Kong \& Malaysia. Sampling duration differs for each country according to availability of data. From 1980.01 to 1998.12 is taken for Thailand \& Malaysia; 1986.05 to 1998.12 for Philippines; 1981.01 to 1998.12 is for Hong Kong \& 1990.01 to 1998.12 for Singapore. Monthly data is taken of stock market index in local currency; exchange rate is expressed as a domestic currency per U.S dollar. Test applied are co integration to find long term association, Multivariate Granger causality is also used to explore short term \& long term dynamics. Result of the study found there is close association between foreign exchange markets \& stock markets.

Empirical findings have a mixed result about the relationship between stock prices $\&$ exchange rates $\&$ the most of the studies were conducted over developed countries so there is further room for investigation of this issue the results of these studies are not convincing. Some studies found positive association between exchange rates \& stock prices.

(Smith 1992, Solnik 1987, Aggarwal 1981) found negative relationship. Contrary to these studies some studies found that there is weak or no relationship between exchange rates \& stock rates (Soenen and Hennigar 1998) and (Franck and Young 1972).when causation is discussed there are also mixed results are found, it is noticed causation runs from exchange rates to stock prices while other studies supports a reverse causation; (Ajayi and Mougoue 1996; Bahmani-Oskooee and Sohrabian 1992) assert the bidirectional causality in the short-run but not in the long run between exchange rates stock prices (Abdalla and Murinde 1997). (Yau and Nieh 2006) apply nonlinear \& linear time series methods by using stock prices of Taiwan \& Japan \& their respected exchange rates (NTD/ Yen) \& found no relationship among the variables.

Study conducted by Muhammad \& Rasheed on four South Asian countries including Pakistan, Bangladesh, Sir-lanka \& India \& found no long term relationship between Pakistan as well as in India but there is bi-directional causality between exchange rates \& stock prices in Bangladesh \& in Srilanka (Muhammad \& Rasheed 2000).

\section{Methodology}

\subsection{Objective of the study}

Objective of this study in broader view is to analyze the long run association between stock prices \& exchange rates. Pakistani rupees is evaluated against KSE 100 index. 


\subsection{Data collection \& Sampling}

The detailed review of the available literature provided an indepth insight into the issues that discuss in international scenario \& specifically its impact in case of Pakistan's financial markets. Researcher curious to investigate at least long enough past data to incorporate most of the changes which affect the included variables to obtain more accurate $\&$ improved results which may differ with shorter time frame in those studies have the variables included by the researcher. Following are the some important historical events which occurred during the period covered by the research $\&$ become the reasons to take this time frame for the research Asian Financial Crises(1997), Subprime Mortgage Crises(2008), Euro Zone Crisis(2009), KSE 100 Index Launched(1991) \& 2008 index crossed the 15000 point bench mark.

System sampling has been used for sampling. The sample data is related to KSE 100 index, Exchange rate from 1993 to 2010 from the statistical data of the state bank of Pakistan website of each variable is included. Quarterly closing values of KSE 100 index, Exchange rate quarter end closing value in terms of Rs/USD is used. To find either long term or short term relationship among the variables an appropriate econometric technique is required. In this paper Engle Granger co-integration technique is implemented to examine the long term relationship between stock prices \& exchange rates.

\subsection{Hypothesis}

- $\mathrm{H}_{\mathrm{o}}$ : There is no long term relationship between stock prices $\&$ exchange rates.

- $\mathrm{H}_{1:}$ There is long term relationship between stock prices \& exchange rates.

\section{Data analysis}

We make use of the co-integration test to analyze the association between stock prices \& exchange rates as the co-integration is a solution to a problem of a spurious regression as a result of the presence of non-stationary data. Even though two non-stationary time series stochastically trending but not drift apart substantially there may exist a long term relationship.

However there many types of test of co-integration but we would apply Augmented Engle-Granger test. In the first step order of integration of the variables is assessed $\&$ in the second step we run the OLS regression. Finally test of stationary will be applied on the residual obtain from the regression.

\subsection{Test of stationary}

- $\mathrm{H}_{\mathrm{ol}} \mathrm{KSE} 100$ index has a unit root.

- $\mathrm{H}_{\mathrm{o} 2}$ Exchange rate has a unit root.

\begin{tabular}{|c|c|c|c|c|c|c|c|}
\hline & & & & le 1 & & & \\
\hline Augme & Dicke & Fuller Tes & Statistics & & & & \\
\hline $\begin{array}{l}\text { Test } \\
\text { Level }\end{array}$ & $\begin{array}{l}\text { Var- } \\
\text { iable }\end{array}$ & $\begin{array}{l}\text { Test } \\
\text { Statis- }\end{array}$ & $\begin{array}{c}\text { P- } \\
\text { Value }\end{array}$ & $\begin{array}{l}\text { Critica } \\
1 \% \\
\end{array}$ & $\begin{array}{l}\text { Jalues } \\
5 \% \\
\end{array}$ & $10 \%$ & Inference \\
\hline Level & & -1.5925 & 0.48 & -3.53 & -2.90 & -2.589 & $\begin{array}{l}\text { Ho Not } \\
\text { Rejected }\end{array}$ \\
\hline $\begin{array}{l}\text { 1st } \\
\text { Differ- } \\
\text { ence }\end{array}$ & KSE & -10.634 & 0.00 & -3.53 & -2.90 & -2.589 & $\begin{array}{l}\text { Ho Re- } \\
\text { jected }\end{array}$ \\
\hline Level & Ex- & -1.5221 & 0.51 & -3.52 & -2.90 & -2.588 & $\begin{array}{l}\text { Ho Not } \\
\text { Rejected }\end{array}$ \\
\hline $\begin{array}{l}\text { 1st } \\
\text { Differ- } \\
\text { ence }\end{array}$ & Rate & -7.2108 & 0.00 & -3.52 & -2.90 & -2.589 & $\begin{array}{l}\text { Ho Re- } \\
\text { jected }\end{array}$ \\
\hline
\end{tabular}

To assess whether time series of both stock prices and exchange rates are stationary or non-stationary we perform Augmented Dickey- Fuller Test Statistics of unit root test as a first step. Result indicates both series are stationary at first difference and both are integrated at the same order now we can further step forward to the second step of testing co-integration. As a second step we run the OLS regression given below.

$$
\mathrm{S}_{t}=\boldsymbol{\alpha}+\text { Bexrate }_{t}+\boldsymbol{\mu}_{t}
$$

Table 2

Dependent Variable KSE

\begin{tabular}{|c|c|c|c|c|}
\hline \multicolumn{5}{|c|}{ No of Observations $=72$} \\
\hline Variables & Coefficient & Std.Error & t-Statistics & Prob. \\
\hline Exrate & 3.9182 & 0.820919 & 4.744917 & 0.000 \\
\hline $\mathrm{C}$ & -5.569236 & 3.25177 & -1.712679 & 0.0912 \\
\hline
\end{tabular}

In the final step we obtain residual from regression as represent in given below equation $\&$ test unit root if residuals are stationary at level or not.

$$
\mu_{\mathrm{t}}=\mathrm{S}_{t}-\boldsymbol{\alpha}-\text { Bexrate }_{t}
$$

\begin{tabular}{|c|c|c|c|c|c|c|}
\hline \multicolumn{7}{|c|}{$\begin{array}{c}\text { Augmented Dickey- Fuller Test Statistics } \\
\end{array}$} \\
\hline \multicolumn{7}{|c|}{ Null Hypothesis: ECT has Unit root } \\
\hline Test & Varia- & Test Statis- & & & ritical & \\
\hline Level & ble & tics & Value & 19 & $5 \%$ & $10 \%$ \\
\hline Level & ECT & -2.03466 & 0.173 & -3.90 & -3.34 & -3.04 \\
\hline
\end{tabular}

Table 3

Results suggest that residuals from the regression are not stationary as we failed to reject null hypothesis. Consequently there is no long run equilibrium relationship found between exchange rates \& stock prices. There is point to be noted that critical values for unit root analysis as suggested by MacKinnon (1991) are only valid for time series data not for estimated values so we used the critical values for co-integration test (Engle-Granger approach) in the residual of a regression suggested by Davidson and MacKinnon (1993).

\section{Conclusion}

There is much debate among the researchers about the association between exchange rates $\&$ stock prices but still there is no conclusive evidence is found. This study is carried with the view to empirically test the mutual association between stock prices \& exchange evidence from Pakistan \& data included from 1993 to 2010 which covers a long enough period to examine the relationship. We conclude that there is no co-integrated relationship found between the stock prices \& exchange rates as supported by the result of empirical analysis of the two time series as EngleGranger approach residual based failed to reject the null hypothesis.

\section{References}

[1] Akhtar, A. (2015). About Karachi Stock Exchange (www.kse.com.pk). [online] Ksestocks.com. Available at: http://ksestocks.com/AboutKSE [Accessed 4 Jan. 2015].

[2] Abdalla, I. and Murinde, V. (1997). Exchange rate and stock price interactions in emerging financial markets: evidence on India, Korea, Pakistan and the Philippines. Applied Financial Economics. 7(1), 25-35. http://dx.doi.org/10.1080/096031097333826.

[3] Aggarwal, R. (1981). Exchange Rates and Stock Prices: A Study of U.S. Capital Market under Floating Exchange Rates, Akron Business and Economic Review.7- 12.

[4] Ajayi, R. and Mougoue, M. (1996). On the dynamic relation between stock prices and exchange rates. Journal of Financial Research. 19(2), 193-207. http://dx.doi.org/10.1111/j.14756803.1996.tb00593.x.

[5] Bahmani-Oskooee, M. and Sohrabian, A. (1992). Stock prices and the effective exchange rate of the dollar. Journal of Applied Economics, 24(4), 459-464. http://dx.doi.org/10.1080/00036849200000020.

[6] Dornbusch, R. and Fischer, S. (1980). "Exchange Rates and the Current Account", American Economic Review, 70(5) 960-971. 
[7] Farooq, M., Keung, W. and Kazmi, A. (2004). Linkage between Stock Market Prices and Exchange Rate: A Causality Analysis for Pakistan. The Pakistan Development Review, 43(4), 639-649.

[8] Franck, P. and Young, A. (1972). Stock Price Reaction of Multinational Firms to Exchange Realignments. Financial Management, 1(3), 66 -73 http://dx.doi.org/10.2307/3665374.

[9] Hatemi-J, A. and Roca, E. (2005). Exchange rates and stock prices interaction during good and bad times: evidence from the ASEAN4 countries. Applied Financial Economics, 15(8), 539-546. http://dx.doi.org/10.1080/09603100500056635.

[10] Jorion, P. (1990). The Exchange-Rate Exposure of U.S. Multinationals. The Journal of Business, 63(3), 331. http://dx.doi.org/10.1086/296510.

[11] Kim, K. (2003). Dollar exchange rate and stock price: evidence from multivariate co-integration and error correction model. Review of Financial Economics, 12(3), 301-313. http://dx.doi.org/10.1016/S1058-3300(03)00026-0.

[12] Morales, L. (2007). The dynamic relationship between stock prices and exchange rates: evidence from four transition economies. Journal of economics international, [n.k.]

[13] Nath, G. C. and Samanta, G. (2003). Relationship between Exchange Rate and Stock Prices in India-An Empirical Analysis. Social science electronic publishing, Inc.

[14] Phylaktis, K. and Ravazzolo, F. (2005). Stock prices and exchange rate dynamics. Journal of International Money and Finance, 24 (7), 1031-1053. http://dx.doi.org/10.1016/i.jimonfin.2005.08.001.

[15] Smith, C., (1992), Stock Market and the Exchange Rate: A Multi country Approach, Journal of Macroeconomics, 14, 607- 629 http://dx.doi.org/10.1016/0164-0704(92)90003-Q.

[16] Smith, C. (1992). Equities and the UK exchange rate. Applied economics, 24(3), 327-335. http://dx.doi.org/10.1080/00036849200000146.

[17] Solnik, B. (1987). Using financial prices to test exchange rate models: A note. The Journal of Finance, 42(1), 141-149. http://dx.doi.org/10.1111/j.1540-6261.1987.tb02555.x.

[18] Yau, H., Nieh, C.C., (2006). Interrelations among Stock prices of Taiwan and Japan and NTD/Yen Exchange Rate. Journal of Asian Economics, $\quad 17 \quad$ (2006), $\quad 535-552$. http://dx.doi.org/10.1016/j.asieco.2006.04.006. 